\title{
Paleoclimate changes inferred from stable isotopes and magnetic properties of organic-rich lake sediments in Arctic Norway
}

\author{
Aina Dahlø Janbu • Øyvind Paasche • \\ Michael R. Talbot
}

Received: 25 June 2009/Accepted: 8 March 2011/Published online: 22 March 2011

(C) The Author(s) 2011. This article is published with open access at Springerlink.com

\begin{abstract}
Stable isotope measures in organic matter are frequently used as indicators of past climate change. Although such analyses can provide valuable information, there is considerable uncertainty associated with studies of organic-rich sediments, especially those from Arctic lakes and bogs. We studied stable isotopes of carbon and nitrogen, and magnetic properties in a sediment core from a small alkaline lake with a high sedimentation rate, Lake Nattmålsvatn, Norway. There is good correspondence among the different sediment variables during the late
\end{abstract}

\section{R. Talbot Deceased.}

Electronic supplementary material The online version of this article (doi:10.1007/s10933-011-9512-2) contains supplementary material, which is available to authorized users.

A. D. Janbu - M. R. Talbot

Department of Earth Science, University of Bergen, Allégt. 41, 5007 Bergen, Norway

A. D. Janbu

Statoil Research Centre, 7000 Trondheim, Norway

$\varnothing$. Paasche

Bjerknes Centre for Climate Research, Allégt. 55,

5007 Bergen, Norway

Present Address:

$\varnothing$. Paasche ( $\square)$

Department of Research Management, University of Bergen, 5020 Bergen, Norway

e-mail: oyvind.paasche@uib.no glacial, and they seemingly reflect major climate variations such as the Allerød Interstade and the Younger Dryas, as well as the transition into the current interglacial. During the early Holocene, however, these relationships are more complex and $\delta^{13} \mathrm{C}$ and $\delta^{15} \mathrm{~N}$ values do not stabilize until $\sim 7,500$ cal year BP. A significant excursion in all variables occurs between 6,850 and 6,500 cal year $\mathrm{BP}$ and is interpreted to represent climate deterioration. Holocene $\delta^{13} \mathrm{C}$ values vary little and indicate that isotopically-depleted dissolved inorganic carbon (DIC) in the lake, possibly influenced by methanotrophy and high $\mathrm{pCO}_{2}$, dominated the lake's carbon cycle. Holocene $\delta^{15} \mathrm{~N}$ is similarly muted, likely due to the availability of abundant dissolved nitrogen. Bulk organic matter is probably dominated by phytoplankton remains produced beneath the ice cover in late spring and during ice breakup when isotopicallydepleted DIC, $\mathrm{pCO}_{2}$ and ammonium availability were maximal. Thus, use of $\delta^{13} \mathrm{C}$ and $\delta^{15} \mathrm{~N}$ as indicators of Holocene paleoclimate and paleoproductivity variation can be challenging in a lake such as Nattmålsvatn, where ice cover isolates the basin for large parts of the year, allowing dissolved respiratory gases to accumulate in the water column. In contrast, magnetic variables appear to better track climate variations. In particular, runoff-driven influx of minerogenic sediments shows high variability that can be attributed to regional changes in Holocene winter precipitation. The most striking shifts occur between 4,000 and 2,300 cal year BP. 
Keywords Stable isotopes - Holocene - Climate . Environmental magnetism · Norway · Arctic

\section{Introduction}

Small lakes respond quickly to environmental changes, adjusting immediately to seasonal temperature shifts, catchment runoff, and spring snow melt. Responses may include algal blooms, precipitation of authigenic calcite, and changes in the composition of the chironomid community. These combined seasonal influences, in addition to external factors, determine the variations in sediment organic matter over time.

In organic-rich lake sediments, organic matter (OM) content can be assessed by weight loss on ignition (LOI) or by measure of total organic carbon (TOC), the latter a measure of the carbon in OM (Dean 1974). Because bulk organic matter has multiple potential sources within and outside the lake, other analyses are required to interpret shifts in OM content. The residual (inorganic) component of the sediment, whether detrital, biogenic silica (diatoms), authigenic carbonate, or a combination thereof, should also be determined.

When organisms die, their remains are subject to microbial decomposition. Net loss of organic matter can be great, and there may be alteration of the primary material. Despite these transformations, the carbon/nitrogen ratio $(\mathrm{C} / \mathrm{N})$ and $\delta^{13} \mathrm{C}$ and $\delta^{15} \mathrm{~N}$ values of bulk organic matter can be used to track the origin of the OM, providing information about the relative contributions of autochthonous versus allochthonous OM to the deposits (Meyers and Lallier-Vergés 1999; Talbot and Johannessen 1992; Filippi and Talbot 2004). Furthermore, the magnetic properties of minerogenic matter that reaches the lake can be used to constrain the external influx of OM identified from isotope measures. Inferring the minerogenic input by means of rock magnetism can also be used to track flood history and other important past environmental events in the catchment (Thompson and Oldfield 1986; Evans and Heller 2003).

The ability of lakes to respond rapidly to environmental changes and to record those changes in their sediment makes lacustrine deposits attractive archives for study of high-frequency paleoclimate oscillations (Bradley 1999). Coastal lakes in Scandinavia are especially suitable for such purposes, as they generally display high sedimentation rates. Many of these lakes were beyond the ice sheet margin during the Younger Dryas (12,900-11,700 cal year BP), suggesting that their sediment records may extend beyond the last glacial-interglacial transition. Several studies have shown that these waterbodies are sensitive to climate fluctuations and that their sediments record regional climate changes (Vorren et al. 1988; Birks et al. 2005; Bjune et al. 2005; Paasche et al. 2007a, b). To our knowledge, no previous study in northern Norway has used carbon and nitrogen isotopes in combination with rock magnetic properties to infer past climate changes on a sub-centennial time scale.

This study addresses the prospects and problems associated with using carbon and nitrogen isotopes as indicators of past climate change in high-latitude lakes with organic-rich sediments. We conducted analyses on a well-dated lacustrine record that spans the entire Holocene and late glacial, at multi-decadal resolution. In addition to recording the withdrawal of the inland ice sheet and/or a local ice cap, the sediment record documents several distinct climatic phases during the Holocene, including a prominent climatic excursion $\sim 6,700$ cal year BP. The challenges associated with using $\delta^{13} \mathrm{C}$ and $\delta^{15} \mathrm{~N}$ in organic-rich lake deposits are highlighted and we emphasize how methanogenesis and seasonal ice cover may dampen the climate sensitivity of the lake.

\section{Study area}

Lake Nattmålsvatn is located in the southeastern part of the large island of Senja, northern Norway (Fig. 1), $170 \mathrm{~m}$ above sea level and $1 \mathrm{~km}$ from the coast $\left(69^{\circ} 10^{\prime} 45.58^{\prime \prime} \mathrm{N} 17^{\circ} 43^{\prime} 23.40^{\prime \prime} \mathrm{E}\right)$. The lake lies outside the marginal moraines of the Younger Dryas (Andersen 1968) as well as those of the Older Dryas, $\sim 14,450$ cal year BP (Sveian pers. commun.). The catchment is composed of Ordovician and Silurian bedrock consisting of garnet mica schist and calcite marble, the latter being dominant. The large amount of carbonate rock, which is mostly calcite, but also contains small amounts of dolomite, contributes to the high $\mathrm{pH}$ and "hardness" of surface water runoff entering Lake Nattmålsvatn. The lake has a summer (July) pH of 8.0 (A. Langangen, pers. commun.). Maximum water depth is $\sim 13 \mathrm{~m}$ and the lake is $200 \mathrm{~m}$ wide and $250 \mathrm{~m}$ long. 


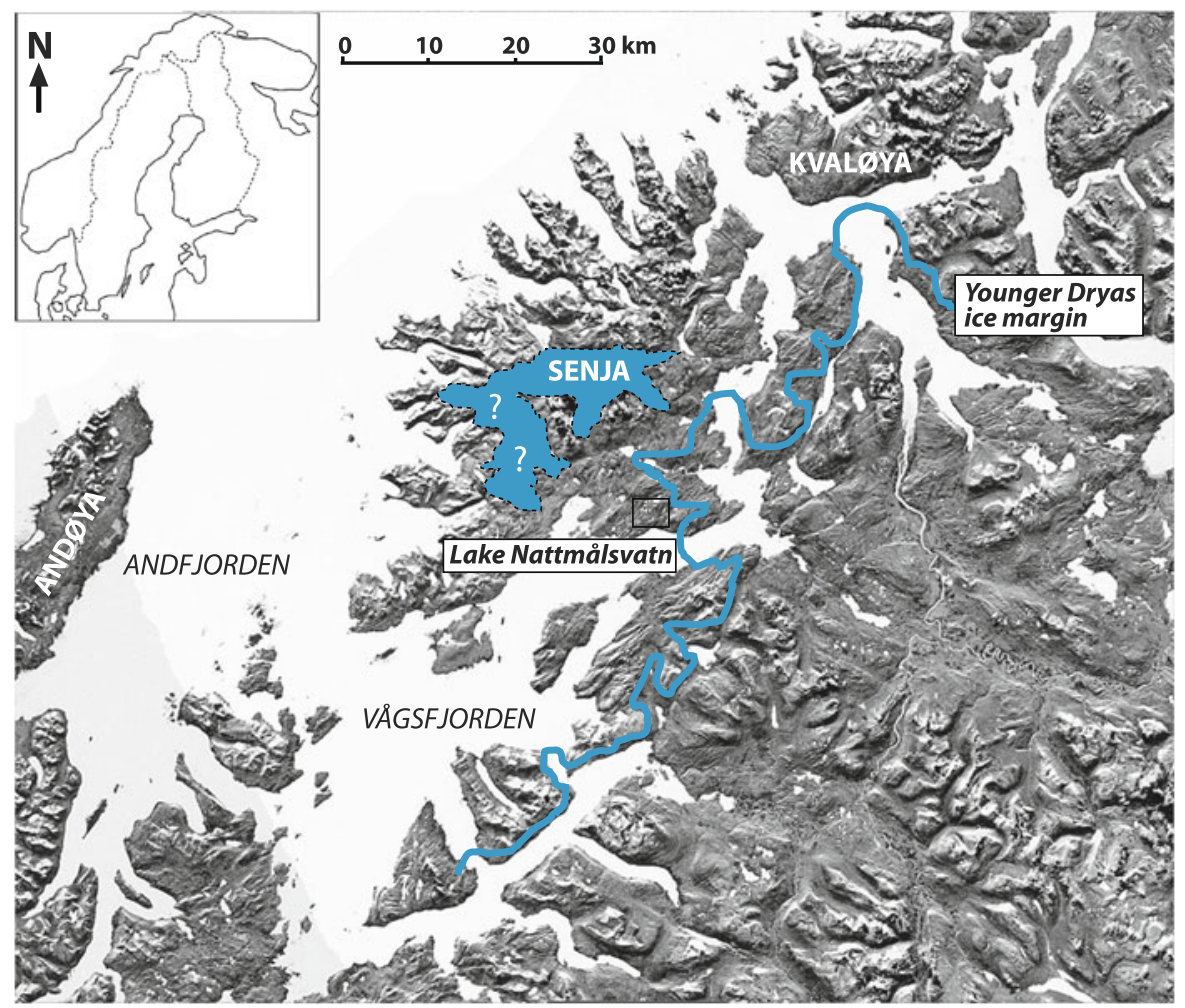

Fig. 1 Outline of Scandinavia (upper left) and satellite image of the study site and its catchment. Lake Nattmålsvatn is situated on the large island Senja $\left(1,586 \mathrm{~km}^{2}\right)$ in northern Norway. The blue lines show the reconstructed ice-sheet margin of the Fennoscandian ice sheet during the Younger

The nearest meteorological station lies $11 \mathrm{~km}$ to the northeast, at Finnsnes. For the period 1961-1990, it recorded a mean annual temperature of $3.2^{\circ} \mathrm{C}$, a July mean of $12.5^{\circ} \mathrm{C}$ and a January mean of $-4.3^{\circ} \mathrm{C}$. Lakes in the region are commonly ice covered from October/November until late May. Mean annual precipitation is approximately $1,000 \mathrm{~mm}$, of which $\sim 35 \%$ falls from May to September, while $\sim 65 \%$ falls from 1 October through April (Klimaavdelingen 1993a, b). Chemical and meteorological data are presented in Table S1.

Lake Nattmålsvatn is currently considered an alkaline Chara lake, with charophytes and marl precipitation during summer (Langangen 1995, 2004). Marl is common in the shallow waters and along the shore. During earlier centuries, local farmers collected the marl for their fields, leaving
Dryas ( 12,500 cal year BP), whereas the dotted blue line indicates a presumed advance of local glaciers on Senja according to Vorren and Plassen (2002), possibly older than the Younger Dryas

holes along the banks. Marl lake sediments are excellent archives of environmental change (Kelts and Hsü 1978; Hollander and McKenzie 1991; Bradbury and Dean 1993; Noe-Nygaard 1995; Hammarlund et al. 2003; Teranes et al. 1999; Leng and Marshall 2004; Diefendorf et al. 2008) and one of our original objectives in this study was to compare the isotopic records from the carbonate and OM fractions in the Lake Nattmålsvatn sediment. Two cores retrieved from the deepest part of the lake, however, yielded almost $6 \mathrm{~m}$ of blackish, organic-rich sediments with no apparent carbonate. The cores also smelled of $\mathrm{H}_{2} \mathrm{~S}$. Despite the fact that Lake Nattmålsvatn is today an alkaline Chara lake according to $\mathrm{pH}$ measurements, there is no evidence in the sediment record for its present state. Our isotope analyses were thus carried out only on the sediment OM fraction. 


\section{Materials and methods}

Core collection and LOI and carbon analyses

Two cores, designated Core I and Core II, were taken $\sim 100 \mathrm{~m}$ apart in March 2002. The cores were collected from the deepest part of the lake using an 11-cm-diameter piston corer (Nesje 1992) operated from surface ice. Both cores were sampled for $\mathrm{LOI}_{550}$ at $0.5-\mathrm{cm}$ intervals by extracting $1 \mathrm{~cm}^{3}$ of wet material. Samples were weighed, dried overnight at $105^{\circ} \mathrm{C}$, and re-weighed to assess percent dry weight. Next, samples were subjected to rising temperatures for half an hour and then combusted at $550^{\circ} \mathrm{C}$ for $1 \mathrm{~h}$ in a Nabertherm controller C6 muffle furnace. After ignition, samples were cooled in a desiccator and reweighed to estimate OM content (Dean 1974). Twenty samples were analysed for TOC using a LECO furnace.

\section{Smear slides}

A full set of smear slides was prepared from Core I to examine the organic material in the sediment. Smear slides were prepared from samples taken every 2-10 cm, except across identifiable sedimentological boundaries, where closer-interval samples were taken. Small samples of moist sediment were prepared for visual examination under a petrographic microscope. Smears were mounted beneath a cover slip using standard epoxy adhesive. Plane- and crosspolarised light and incident UV radiation were used to examine the slides. Analysis showed that sediments are composed of a variety of minerogenic and organic components, including authigenic minerals, notably pyrite and feldspar at some depths in the core.

Isotope and elemental analysis

Core I was subsampled every $4 \mathrm{~cm}$ for organic carbon $\left(\delta^{13} \mathrm{C}\right)$ and nitrogen $\left(\delta^{15} \mathrm{~N}\right)$ isotope analysis of bulk organic matter $(\mathrm{OM})$, total organic carbon (TOC) and total nitrogen (TN) content. Sample aliquots were reacted with $1 \mathrm{M} \mathrm{HCl}$ at $50^{\circ} \mathrm{C}$ to remove possible traces of carbonate. After $24 \mathrm{~h}$, samples were rinsed in distilled water five times and dried in an oven at $40^{\circ} \mathrm{C}$. Dried samples were then crushed in an agate mortar to homogenize them and reduce grain size. There has been concern about whether components of the nitrogen isotopic composition are lost when samples are reacted in $\mathrm{HCl}$ and oven-dried (Meyers and Teranes 2001). We thus ran 20 freeze-dried and homogenised bulk samples from the same levels that were prepared using $\mathrm{HCl}$ and by oven-drying, to test if there were differences between results derived from the two preparation methods (Table S2). Because we found no large discrepancy between the methods, the $\mathrm{HCl}$ treatment was applied to the nitrogen isotope samples throughout the core. All isotope samples were analysed according to standard methods at Iso-Analytical Inc., England, with an elemental analyser connected to a continuous flow isotope-ratio mass spectrometer. Analytical precision was $\pm 0.3 \%$ for $\delta^{15} \mathrm{~N}$ and $\pm 0.1 \%$ for $\delta^{13} \mathrm{C}$. The elemental analyser provides measurements of total organic carbon (TOC) and nitrogen content (TN). There was no evidence for presence of inorganic nitrogen (Talbot 2001), and TN thus reflects total organic nitrogen. In this study, $\mathrm{C} / \mathrm{N}$ ratios are expressed as weight percent. Carbon isotope values are reported in standard $\delta$ notation (\%o) relative to VPDB (PeeDee Belemnite) (Coplen 1982), and nitrogen values are reported with respect to atmospheric nitrogen (AIR).

\section{Magnetic variables}

Magnetic susceptibility ( $\chi$ bulk), anhysteretic remnant magnetization (ARM), and saturation isothermal remnant magnetization (SIRM), were measured to characterize the minerogenic material deposited in the lake. Such measurements permit discrimination between, for instance, glacial and non-glacial sediments, as reflected in changes in the strength of the signal or shifts in the S-ratio $\left(\mathrm{IRM}_{100 \mathrm{mT}} / \mathrm{sIRM}_{2 \mathrm{~T}}\right)$. Such data can be used to identify the end of deglaciation and to characterize the input of detrital material throughout the Holocene.

Core I was sampled for magnetic analyses with plastic boxes every $1 \mathrm{~cm}$ throughout the core $(n=489)$. Initial magnetic susceptibility ( $\chi$ bulk) was determined on both wet and dry samples using a KLY-2 induction bridge with a sensitivity of $4 \times$ $10^{-8}$ SI. ARM was imposed with a $0.1 \mathrm{mT}$ DC field and a $100 \mathrm{mT}$ AC-field in a $2 \mathrm{G}$ af-demagnetizer on contiguous samples collected from the basal $89 \mathrm{~cm}$ of the core $(489-400 \mathrm{~cm}$ depth; $n=89)$. SIRM was obtained for the same interval $(489-400 \mathrm{~cm}$ depth; 
$n=89)$ using an ASC IM10-30 Impulse Magnetizer for which saturation levels (SIRM) were assumed by applying a 2T field. Because there was little difference between measurements performed with $1 \mathrm{~T}$ and $2 \mathrm{~T}$ fields $(n=20)$, we assume that "saturation" was obtained with a $2 \mathrm{~T}$ field. Backfield measurements were performed after exposing the samples to a $100 \mathrm{mT}$ field $\left(\mathrm{IRM}_{-100 \mathrm{mT}}\right)$. Subsequently, the S-ratio was used to indicate the dominant magnetic mineralogy (Stober and Thompson 1979). Low values represent the presence of canted-ferromagnetic minerals such as $\alpha-\mathrm{Fe}_{2} \mathrm{O}_{3}$ (haematite) and high values represent the presence of ferromagnetic minerals such as $\mathrm{Fe}_{3} \mathrm{O}_{4}$ (magnetite). Magnetic susceptibility was measured on splits from Cores I and II using a Bartington instrument equipped with a MS2E surface sensor. Measurements were performed in the Paleomagnetic Laboratory at the University of Bergen, Norway or at the Magnetic Laboratory at ETH, in Zürich, Switzerland.

Core chronology

Terrestrial plant macrofossils were carefully handpicked from the core for AMS radiocarbon dating. Samples were washed with distilled water, dried and sealed in sterile glass containers before dating at the Poznań Radiocarbon Laboratory, Poland. Dates were calibrated using CALIB 5.1 (Stuiver et al. 2005) (Table S3). All reported dates are calibrated intercept dates that used the one-sigma range (weighted mean). Because the upper $60 \mathrm{~cm}$ in core I are missing (Fig. 2), the three dates from this core were shifted accordingly.

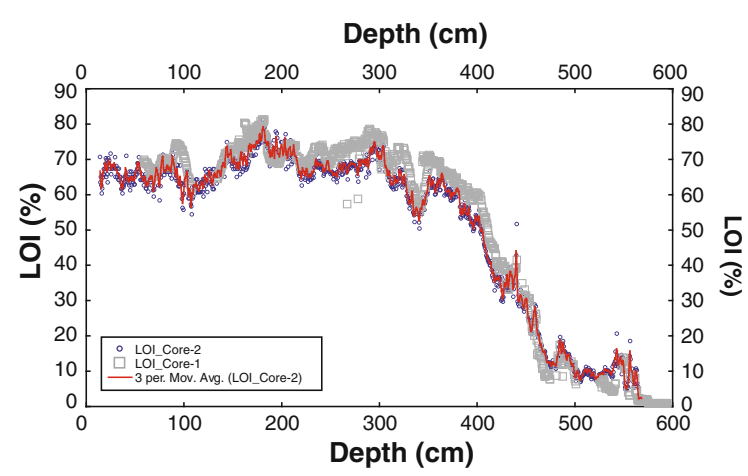

Fig. 2 Loss-on-ignition (LOI) stratigraphies from Cores I and II. The stratigraphies display very good co-variation in both LOI trends and amplitude. This comparison illustrates that Core $\mathrm{I}$ is missing $60 \mathrm{~cm}$ at the top

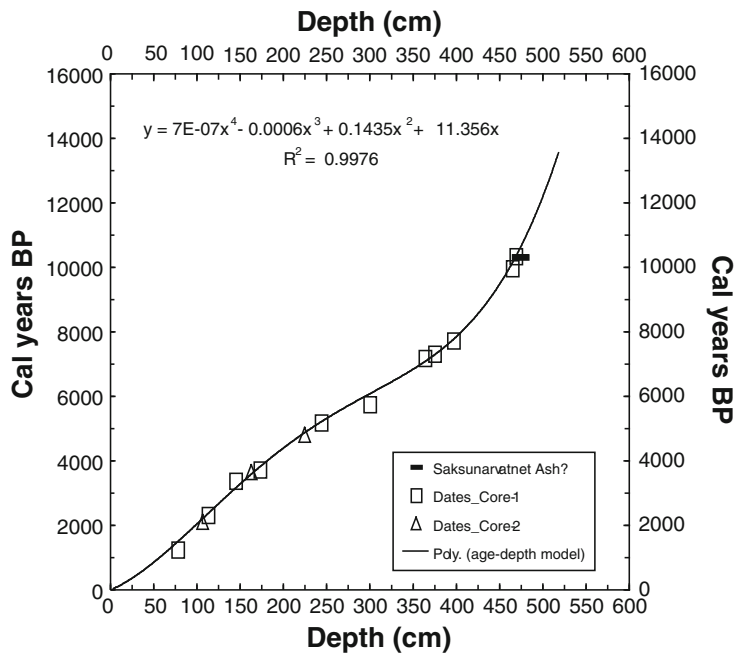

Fig. 3 Terrestrial macrofossil dates from Core I (squares) and Core II (triangles) were combined to form a composite agedepth model for Lake Nattmålsvatn. A polynomial fit was used to establish the model. Based on downcore variations in LOI and the missing material at the top of Core I (Fig. 2), dates from Core I were adjusted by $60 \mathrm{~cm}$ with respect to their initial depth

A polynomial was used to construct an age-depth model for both cores. None of the 14 dates on macrofossils show an age-depth reversal (Fig. 3). The sedimentation rate has remained high and stable for most of the Holocene. The model age for a peak in magnetic susceptibility, which might represent the Saksunarvatnet Ash (Mangerud et al. 1986), is in good agreement with the known age of the ash, 10,347 years before AD 2000 (Rasmussen et al. 2007).

\section{Results}

The late glacial record

Visual inspection of the lower part of Core I revealed firm grey clay and silt with isolated clasts, with a sharp transition to overlying, finely laminated, greenish-grey silt. The next $50 \mathrm{~cm}$ consist of alternating silty laminae and silty gyttja laminae, characterised by abundant mm-size flakes of muscovite. From $\sim 405 \mathrm{~cm}$, there is a transition from greenish silt to dark-brown gyttja that continues from $370 \mathrm{~cm}$ to the top of the core (Fig. 4).

No macrofossils were located in the lowest part of the core. Ages before 10,370 cal year BP were 
Depth (cm)

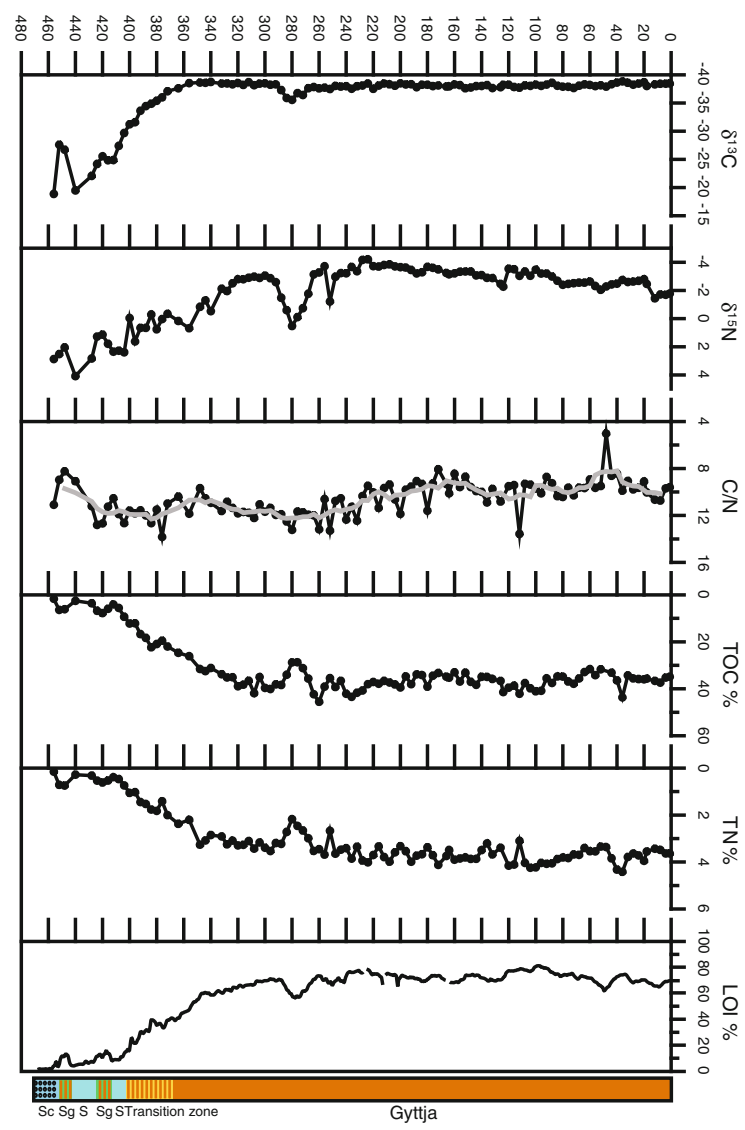

Fig. 4 Stable isotope values $\left(\delta^{13} \mathrm{C}\right.$ and $\left.\delta^{15} \mathrm{~N}\right)$, carbon/nitrogen $(\mathrm{C} / \mathrm{N})$ ratio, total organic carbon $(\mathrm{TOC} \%)$, and total organic nitrogen $(\mathrm{TN} \%)$ plotted against depth $(\mathrm{cm})$. Sc Silty clay (this unit also contains clasts), $S g$ Silty gyttja, and $S$ Silt

obtained by extrapolation and therefore have large associated uncertainties. Mean late glacial sampling resolution is $\sim 30$ years $/ \mathrm{cm}$ and somewhat better for the Holocene. Relatively large clasts embedded in silty clays in the lowermost part of the core are thought to reflect deglaciation.

Throughout the late glacial part of the core, $\chi$ bulk, ARM and SIRM values are generally higher than in the Holocene section (Figs. 5, 6). A stepwise decline culminates in the interval from 456 to $446 \mathrm{~cm}$, which may correspond to the Allerød Interstade. The magnetic mineralogy, inferred from the S-ratio, suggests a gradual shift from "harder" to "softer" minerals, with a few exceptions indicated by lower values (Fig. 7). A prominent peak in ARM, SIRM, and particularly $\chi$ bulk, obscures what would otherwise be a clear transition from the late glacial to the
Holocene (Fig. 6). This peak is anomalous compared to the remainder of the record, with $\chi$ bulk values reaching $10^{-6} \times 1.97 \mathrm{~m}^{3} \mathrm{~kg}^{-1}$.

Smear slides revealed a variety of grains derived from the catchment, notably quartz, feldspar and mica. In addition, the section between about 445 and $400 \mathrm{~cm}$ is characterised by abundant authigenic pyrite framboids (Fig. 8).

Organic matter is absent below $455 \mathrm{~cm}$, so isotopic analysis of OM was only possible on samples from that depth and above (Fig. 4). The earliest part of the record shows a negative $\delta^{13} \mathrm{C}$ excursion during the Allerød Interstade. Thereafter, following a return to higher $\delta^{13} \mathrm{C}$ values, $\delta^{13} \mathrm{C}$ decreases steadily upward through this section of the core, a trend that is also apparent in the early-late Holocene $\delta^{13} \mathrm{C}_{\mathrm{OM}}$ records from other marl lakes (Diefendorf et al. 2008). $\delta^{15} \mathrm{~N}$ also decreases upward, but in a more irregular fashion than the carbon isotopes (Fig. 5).

$\mathrm{LOI}_{550}$ values tend to be correlated inversely with magnetic susceptibility during the late glacial (Fig. 6). A rapid increase in $\mathrm{LOI}_{550}$, from $1-2$ to $10-11 \%$, occurs at the onset of the Allerød, $\sim 13,500$ cal year BP. There is an equally swift return to lower values (5\%) at the onset of the Younger Dryas, $\sim 12,700 \mathrm{cal}$ year BP. At 11,500 cal year BP, values rise again, but a temporary return to lower values is associated with the previously described anomaly in magnetic properties. Based on the results presented above, three sedimentary phases (P4-P6), representing late glacial changes, were recognized in Core I (Fig. 7).

The Holocene record

From 10,300 to 6,800 cal year BP, LOI values gradually increase, from less than 10 to more than $70 \%$ (Figs. 5, 6). During the first 1,000 years of this period, the LOI increased stepwise, but during the latter 2,500 years of this period, the increase was smoother. At 6,800 cal year BP, LOI declined by $\sim 15 \%$ (Fig. 6) for about 500 years. During the rest of the Holocene LOI values are extremely high, reaching a maximum of $\sim 81 \%$ at 3,500 cal year BP, after which they declined for 1,300 years, to $60 \%$.

Holocene variations in $\chi$ bulk indicate that the influx of minerogenic matter after 9,500 cal year BP was low, although values averaged $10^{-7} \times 1.48 \mathrm{~m}^{3}$ $\mathrm{kg}^{-1}$. There were marked strengthenings of magnetic susceptibility twice during the late Holocene (Fig. 6). 
Fig. 5 Stable isotope values $\left(\delta^{13} \mathrm{C}\right.$ and $\left.\delta^{15} \mathrm{~N}\right)$ and magnetic susceptibility ( $\chi$ bulk) measurements through the Holocene. Note the similar decreasing trends between 10,000 and 7,500 cal year BP, and also the similar response in all three variables between 6,850 and 6,300 cal year BP. There are two-fold increases in $\chi$ bulk at 4,000 and 2,300 cal year BP

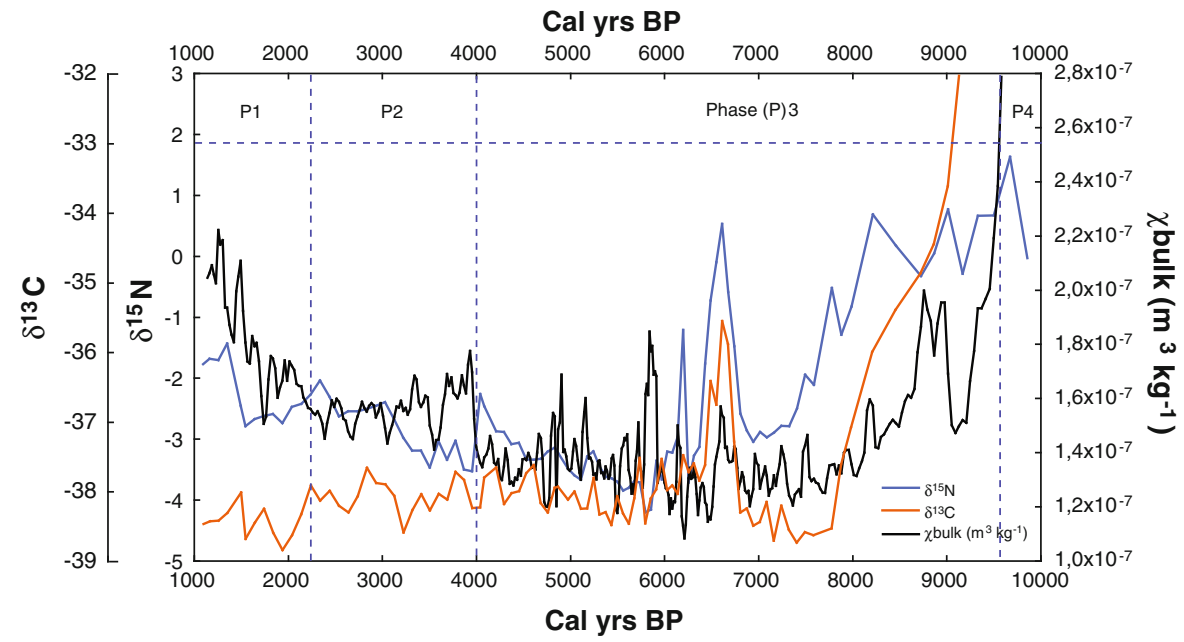

Cal yrs BP

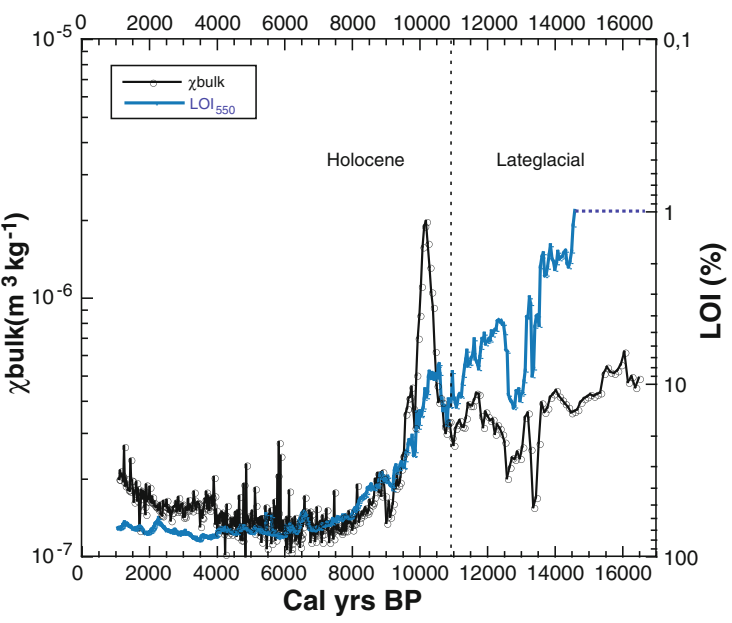

Fig. 6 Magnetic susceptibility ( $\chi$ bulk, left $y$-axis and logscale) and LOI (\%, right $y$-axis, values are reversed and on logscale) variations through the late glacial and Holocene. Note the strong inverse relationship between LOI and $\chi$ bulk during the entire late glacial period

The first increase began around 4,000 cal year BP, at which time higher values were attained rapidly. After 2,300 cal year BP, values began to increase further, a trend that continues towards the top of the core with $\chi$ bulk values of $10^{-7} \times 2.15 \mathrm{~m}^{3} \mathrm{~kg}^{-1}$.

Smear slides illustrate the organic-rich nature of the Holocene sediments and contain little siliclastic material (mainly quartz), suggesting minimal input of minerogenic grains from the surrounding landscape. The organic fraction contains unstructured (amorphous) material of probable algal origin, as well as

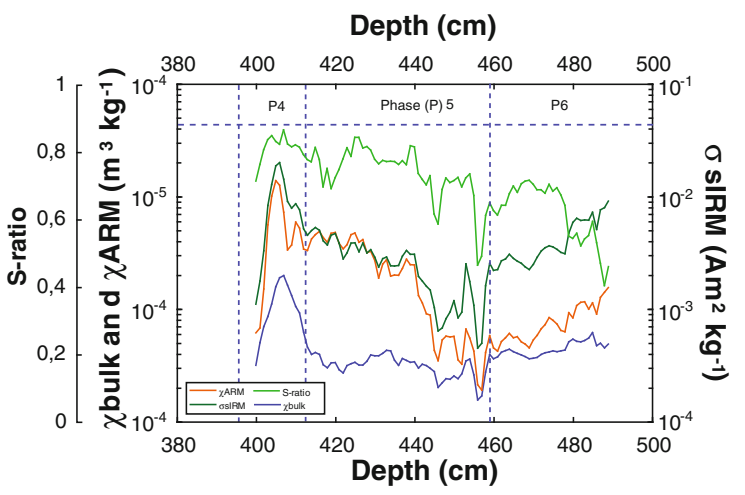

Fig. 7 Variations in $\chi$ bulk and $\chi \mathrm{ARM}$ (left $y$-axis, log-scale) and SIRM (right $y$-axis, log scale) throughout the lower part of Core I. The peak $\sim 405 \mathrm{~cm}$ depth might represent the Saksunarvatn Ash (10,347 before AD 2000). A change in magnetic mineralogy is indicated by the $\mathrm{S}$-ratio (left, $y$-axis), where 'softer' minerals such as magnetite $\left(\mathrm{Fe}_{3} \mathrm{O}_{4}\right)$ are associated with values close to 1

from higher plants, in particular well preserved remains of the moss Drepanocladus sp., and from a variety of aquatic invertebrates (Fig. 8). Diatoms are few, small and poorly preserved from the beginning of the Holocene until ca. 5,500 cal year $\mathrm{BP}$, but thereafter become abundant, with a pronounced increase in large species. Early Holocene sediments contain euhedral, in some cases elongate, crystals of feldspar, showing typical albite twinning (Fig. 8). Their perfect crystal form strongly suggests they are authigenic feldspar. The crystals become rare and eventually disappear around 5,000 cal year $\mathrm{BP}$, at the same time diatoms become abundant. 


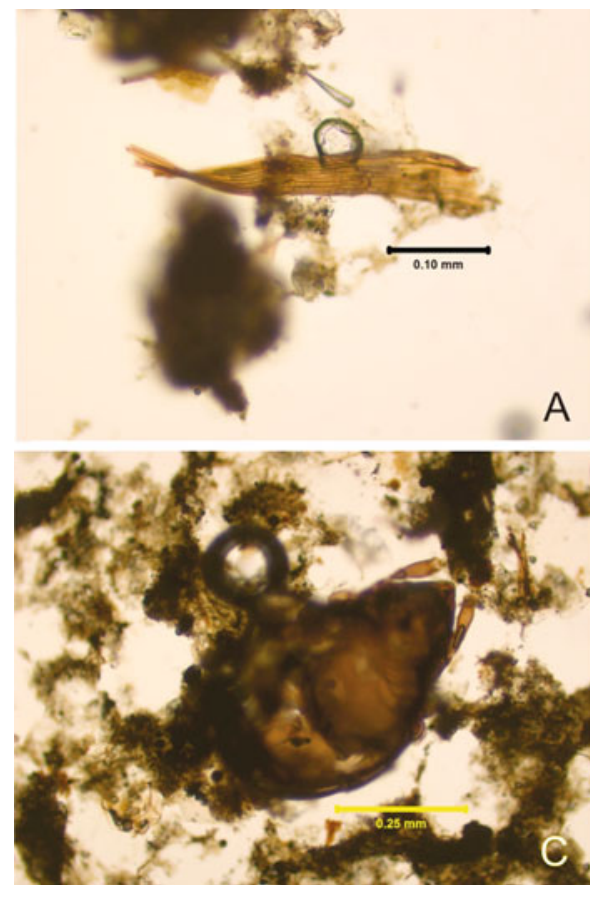

Fig. 8 Photomicrographs of smear slides showing some notable features of the Lake Nattmålsvatn sediments. a Fragment of the moss Drepanocladus sp., a characteristic component of the preserved organic matter. b Pyrite framboids (black

The $\delta^{13} \mathrm{C}$ record from the earliest Holocene continues the trend seen in the late glacial. From the Younger Dryas, there is a transition to lower $\delta^{13} \mathrm{C}$ values in the Holocene. The $\delta^{13} \mathrm{C}_{\text {org }}$ curve stabilizes $\sim 8,000$ cal year $\mathrm{BP}$ and values remain low $(<-38.3 \%$ ) for the rest of the Holocene, except for a short period of isotope enrichment at 6,700-6,400 years BP, the Atlantic period, corresponding to the lower LOI values described above (Fig. 5).

Nitrogen isotope values $\left(\delta^{15} \mathrm{~N}_{\text {org }}\right)$ also display a trend to progressively lower values into the Holocene, but not as smooth a trend as for $\delta^{13} \mathrm{C}_{\text {org }}$ (Fig. 5). The Younger Dryas and perhaps the Preboreal Oscillation (PBO) have the highest values, around +2.2 to $+4 \%$, probably because immature soils provided the dominant source of nitrogen during this period (Wolfe et al. 1999; Talbot 2001). $\delta^{15} \mathrm{~N}$ values stabilise at relatively low values, -4 to $-2 \%$, at around 7,500 cal year BP, and remain low for the rest of the Holocene, except for a period of isotope enrichment in the Atlantic period, as seen for carbon isotope ratios (Fig. 5). There are, however, slight

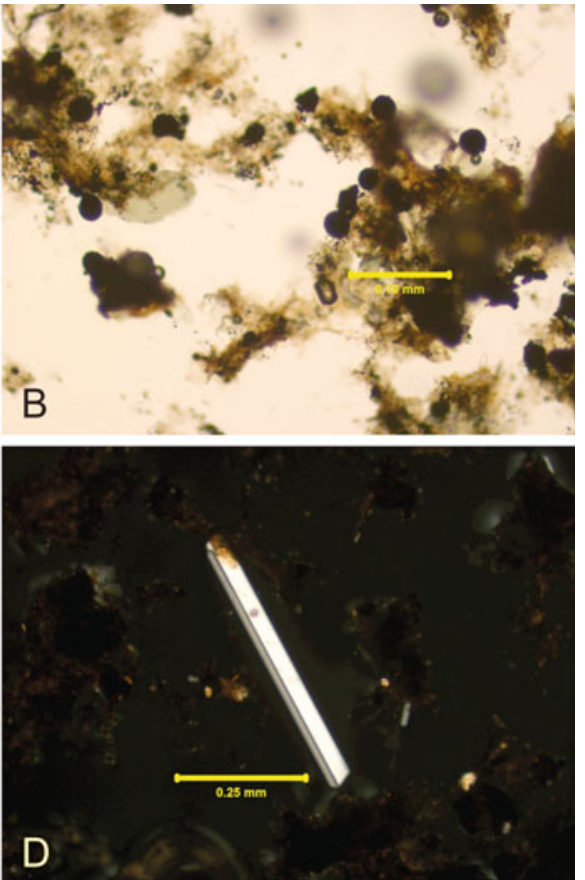

spherules) produced by microbial sulphate reduction. c Unidentified aquatic invertebrate. d Elongate, euhedral authigenic feldspar showing typical albite twinning. Cross-polarised light

temporal differences between the trends in carbon and nitrogen isotope signals during this period (Fig. 5). After about 3,200 cal year BP the nitrogen isotope ratios increase slightly, but display relatively low variability.

\section{Discussion}

Sources of organic matter in sediments

In Lake Nattmålsvatn sediments, $\mathrm{C} / \mathrm{N}$ ratios range from 8 to 13 (Fig. 4), which indicates that organic matter comes predominantly from aquatic sources and that in-lake production is high. Organic matter delivered to the lake from the catchment is moderate by comparison. The shift from a $\mathrm{C} / \mathrm{N}$ ratio of $\sim 12$ at $\sim 6,000$ to $\sim 9$ at $\sim 4,000$ cal year BP indicates a decline in delivery of organic matter from the terrestrial environment, increased lake bioproduction, or both (Figs. 4, 5). Prior to 8,000 cal year BP, TOC and TN are highly correlated $(r=0.99, P<0.001)$. A linear fit of the data indicates a mean $\mathrm{C} / \mathrm{N}$ of $\sim 11$ 


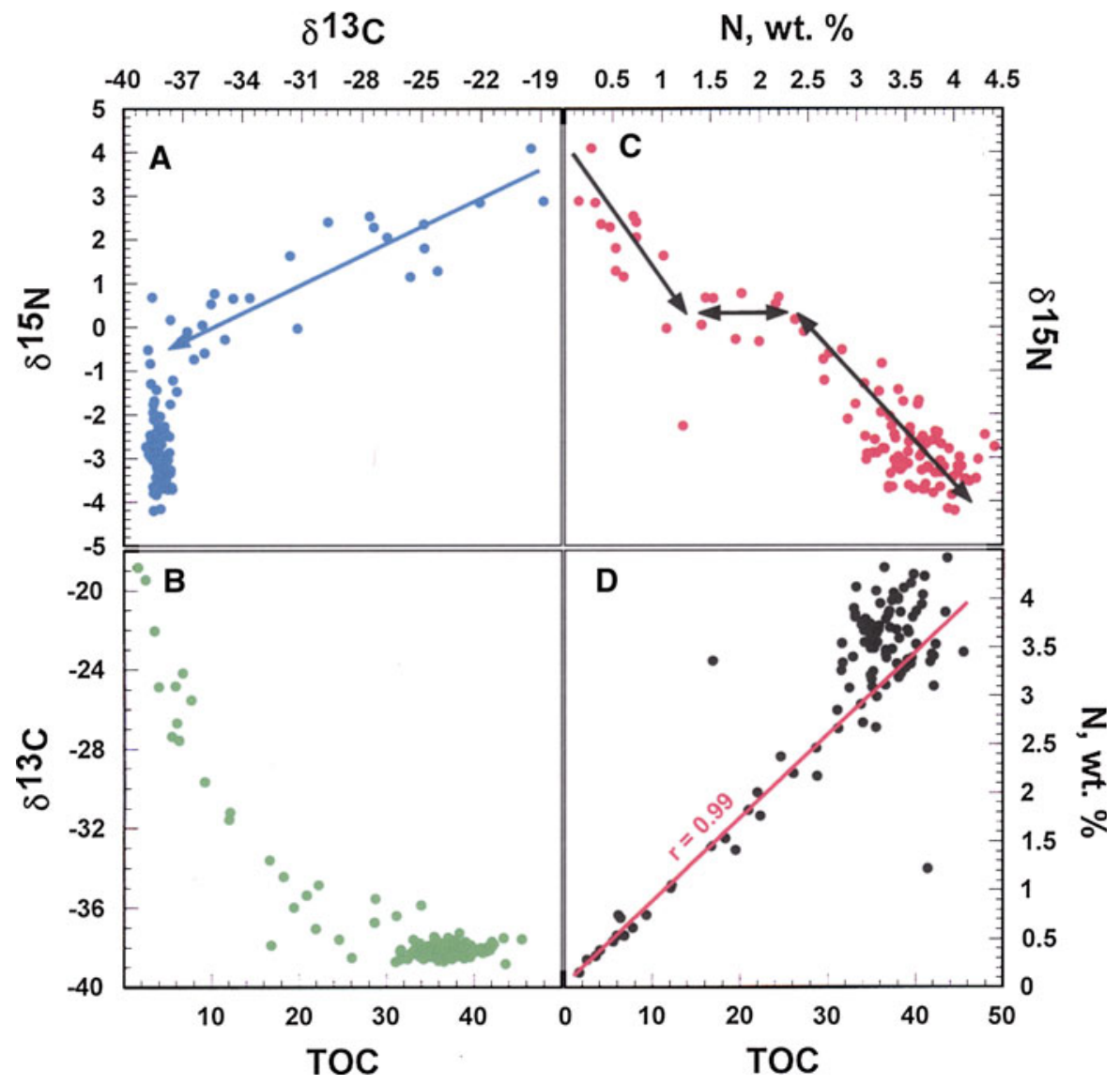

Fig. 9 Cross-plots of the most significant isotope and elemental variables. a $\delta^{13} \mathrm{C}$ versus $\delta^{15} \mathrm{~N}$ showing a positive correlation for the late glacial to earliest Holocene section. This correlation breaks down once $\delta^{13} \mathrm{C}$ values stabilise at $-38.1 \%$. The arrow shows the trajectory followed by the isotopic data during the late glacial-Holocene transition. b $\delta^{13} \mathrm{C}$ versus TOC. An inverse correlation exists in the early part of the record, but the relationship breaks down, as in plot $\mathrm{A}$, when $\delta^{13} \mathrm{C}$ values drop below $-38 \%$ o. c $\delta^{15} \mathrm{~N}$ versus TN\%. Similar to the $\delta^{13} \mathrm{C}$ versus TOC plot (b), there is an overall inverse correlation, however in the case of nitrogen, the relationship is

(Fig. 9). After $c a$. 8,000 cal year BP, and in recent times, this relationship breaks down and the data are poorly correlated $(r=0.22)$ and show slight $\mathrm{N}$ enrichment (mean $\mathrm{C} / \mathrm{N}=10.2$ ) in relation to the older deposits (Fig. 9). This change may reflect conversion of Lake Nattmålsvatn from an oligotrophic to a eutrophic waterbody, a change that was probably driven by the onset of warmer climate.

Organic matter is frequently a minor constituent of lake sediments. In Lake Nattmålsvatn, organic matter dominates the sediment mass, with maximum LOI values near $82 \%$ (Fig. 2). We assume that the residual stepped, with a transition to higher TN at $c a$. 8,000-7,000 cal year BP. This was due to a change from oligotrophy to eutrophy. The single arrow shows the direction of change during the late glacial, the double arrows show the range of variation during the transition period and the Holocene. d TOC versus TN. A strong positive correlation is seen for the late glacial to earliest Holocene part of the record and mean $\mathrm{C} / \mathrm{N}$ was 11. Once the lake became eutrophic the TOC/TN relationship broke down and the data formed a poorly correlated cluster with a mean $\mathrm{C} / \mathrm{N}$ of 10.2 , i.e. slightly $\mathrm{N}$-enriched relative to earlier deposits

material from the loss-on-ignition procedure consists largely of diatoms, given the low MS signal and the smear slide observations.

Stable isotopes

Both $\delta^{13} \mathrm{C}$ and $\delta^{15} \mathrm{~N}$ display large ranges, $\sim 20$ and $\sim 9 \%$, respectively, suggesting major changes in carbon and nitrogen cycling throughout the postglacial history of Lake Nattmålsvatn. In the late glacial, there were $\delta^{13} \mathrm{C}$ values greater than $-25 \%$. Sediments of that phase consist of silt with low TOC 
content, alternating with silty gyttja. This reflects a pioneer phase with little catchment vegetation. Dissolution of detrital carbonate and exposed marble bedrock would have been the principal source of DIC at that time, contributing isotopically enriched runoff to the lake, which in turn would generate $\mathrm{OM}$ with relatively high $\delta^{13} \mathrm{C}$ values. A similar scenario is apparent in Lough Inchiquin (Eire), where the limestone bedrock dominated the isotopic composition of lake OM during the immediate post-glacial period (Diefendorf et al. 2008).

Evidence for weathering of labile glacial detritus is also provided by abundant pyrite framboids in parts of this section, which were formed by microbial sulphate reduction. The dissolved sulphate required for pyrite formation probably came from the oxidation of detrital pyrite in tills derived from mica schist. Pyrite is absent from younger deposits, despite the anoxic conditions that must have prevailed in such organic-rich sediments. Once all detrital pyrite had been removed from the glacial deposits, there presumably was no other source of sulphate, and bacterial sulphate reduction was no longer an important process in Holocene lake sediments.

The isotope and elemental data display some interesting relationships (Fig. 9). During the initial postglacial period, there is a positive correlation between $\delta^{13} \mathrm{C}$ and $\delta^{15} \mathrm{~N}$ (Fig. 9), but this breaks down around 8,000-7,000 cal year BP when $\delta^{13} \mathrm{C}$ stabilises at $-38.1 \pm 0.3 \%$, while $\delta^{15} \mathrm{~N}$ varies over a range $\sim 5 \%$ (Fig. 9). At the same time there is a shift in the $\delta^{15} \mathrm{~N}$ vs. TN relationship (Fig. 9), as the OM displays a much higher TN content. This change supports our inference that the transition from oligotrophic conditions that prevailed during the late glacial, to eutrophic conditions, occurred at ca. 8,000 cal year BP (Fig. 5).

The $\delta^{15} \mathrm{~N}$ and $\delta^{13} \mathrm{C}$ in the early part of the record show an inverse correlation with $\mathrm{TN}$ and TOC, respectively. This is opposite to what is expected if variations in isotopic composition are driven by primary productivity (Hollander and McKenzie 1991; Bade et al. 2004). The inverse relationships suggest, instead, that the DIC and DIN pools available for primary production were not limited. Development of ice cover for 5-7 months each year may have contributed to this DIC and DIN availability. Respiration of sediment OM during winter months can lead to accumulation of dissolved and free gases beneath the ice, notably carbon dioxide, methane, ammonia and nitrous oxide (Wetzel 2001), with concentrations well in excess of those resulting from equilibrium with the atmosphere (Kortelainen et al. 2000; Striegl et al. 2001; Huttunen et al. 2003a, b). Primary production may also continue beneath the ice (Wetzel 2001). Although it is likely that production in Lake Nattmålsvatn was low during the dark winter months, high insolation at these northern latitudes during April and May could have stimulated high rates of primary production beneath the ice at a time when dissolved nutrients would have been at their highest concentrations. Very low Holocene $\delta^{13} \mathrm{C}$ values may reflect assimilation of this DIC pool under the ice and during the ensuing period of ice-out, when primary production reaches a peak (Boström and Pettersson 1977). Carbon isotope values lower than about $32 \%$ suggest that methane oxidation has contributed $\mathrm{CO}_{2}$ to the DIC pool (Rau 1978; Whiticar and Faber 1986). Another reason for the low values may be elevated $\mathrm{pCO}_{2}$, as fractionation increases with increased $\mathrm{CO}_{2}$ concentration (Degens et al. 1968). The remarkably constant $\delta^{13} \mathrm{C}$ record for the Holocene suggests that Lake Nattmålsvatn was, and still is, a well-buffered system. We do not, however, have a good explanation for why the $\delta^{13} \mathrm{C}$ value for Holocene OM stabilized at $-38.1 \pm 0.3 \%$.

Abundance of dissolved nitrogen species may also explain the low $\delta^{15} \mathrm{~N}$ values $(<0 \%$ ). Like $\mathrm{C}$ isotopes in organic matter, $\mathrm{N}$-isotope fractionation increases with rising $\mathrm{N}$ availability (Talbot 2001). Unlike the $\delta^{13} \mathrm{C}$ record, however, $\delta^{15} \mathrm{~N}$ did not stabilise at a fixed value, but varied over a range of $\sim 2 \%$, probably due to variations in $\mathrm{N}$ availability, likely in the form of ammonia (Billaud 1968), and drawdown of the DIN reservoir as the spring bloom proceeded.

Low $\delta^{13} \mathrm{C}$ and $\delta^{15} \mathrm{~N}$ values in Holocene OM were interrupted only by higher values from 6,850 to 6,500 cal year BP (Fig. 5). Nitrogen isotopes, in particular, suggest a return at that time to near-lateglacial conditions. Concomitant reductions in TOC, TN and LOI, accompanied by the rise in $\delta^{15} \mathrm{~N}$ and a small rise in $\mathrm{C} / \mathrm{N}$ (Figs. 4, 5), are consistent with a reduction in lake productivity and an increased supply of plant and soil OM to the lake. As mentioned, we interpret this excursion to be the result of a previously unrecognised brief period of cooling in Arctic Norway.

Feldspar authigenesis also provides insight into the state of the lake. The paucity of diatoms in the 
feldspar-bearing section suggests that the silica necessary for feldspar precipitation may have been provided by diatom dissolution. The solubility of opaline silica increases dramatically at $\mathrm{pH} \geq 8$. Diatom dissolution probably occurred when the lake was at least seasonally alkaline, with a $\mathrm{pH}$ greater than the current 8 . Such conditions could have been achieved in a climate warmer and drier than today's, when high rates of primary production and greater summer evaporation led to elevated surface water $\mathrm{pH}$. Increased diatom abundance and the accompanying disappearance of feldspar after $c a$. 5,500 cal year BP suggest a change to less alkaline conditions, probably due to a transition to a cooler, wetter climate that characterised the later Holocene in the Senja region.

\section{Correlation of TOC and LOI}

Overall, there is a strong correlation between LOI and TOC (Fig. 10), but Fig. 10 also reveals a result not previously described in the literature. Above $\sim 60 \%$ LOI, corresponding to $\sim 32 \%$ TOC, there is a wide scatter of values, and correlation between the two variables in this group of high values is poor (Figs. 9, 10). Lacustrine sediments with such large amounts of

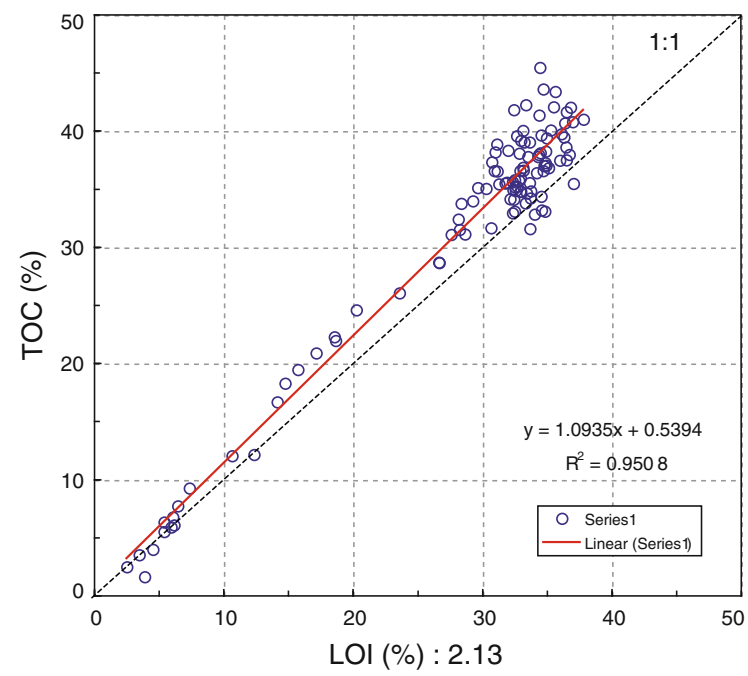

Fig. 10 Total organic carbon (TOC \%) plotted against Losson-ignition (LOI \%). Original LOI values were divided by 2.13, according to Dean (1974) to approximate the amount of TOC in bulk organic matter. TOC values from Lake Nattmålsvatn are consistently higher than the 1:1 relationship, indicating that Dean's (1974) empirical constant (2.13) is too high for Lake Nattmålsvatn. The relationship generally breaks down when TOC values are $>30 \%$
$\mathrm{OM}$ are rare, and the LOI and TOC values exceed those that Dean (1974) used to develop the LOI-TOC relationship. There are several possible explanations for the breakdown of the correlation at high concentrations: (1) LOI was measured with error at such high concentrations of $\mathrm{OM}$, perhaps due to incomplete ignition at $550^{\circ} \mathrm{C}$, (2) high concentrations of TOC overwhelm the elemental carbon analyser, resulting in artificially low carbon counts, (3) The linear relationship between LOI and TOC does in fact break down when OM content exceeds $\sim 60 \%$, (4) The concentrations above which the relationship breaks down, $60 \%$ LOI and $32 \%$ TOC, occur at a depth (age) in the core when there is a shift from low values in the deglacial and early Holocene to higher values in the middle and late Holocene, perhaps suggesting a change in $\mathrm{OM}$ processing starting $\sim 7,000$ cal year BP $(312 \mathrm{~cm})$.

We speculate that 3 and 4 above, i.e. extremely high LOI values $(>60 \%)$ in combination with a change in OM composition, are responsible for the poor relationship between LOI and TOC. Below $60 \%$ LOI there is a very strong correlation between the two variables $(r=0.99, P<0.001)$ (Fig. 10). As noted above, there is a gradual decrease in $\mathrm{C} / \mathrm{N}$ ratio after the middle Holocene, indicating an increasing proportion of nitrogen-rich $\mathrm{OM}$ in sediments, originating from lake primary production. This is also evident in the \% TN curve, which shows the highest nitrogen concentrations in the latest part of the Holocene (Fig. 5). Alternatives (1) and (2) were rejected for several reasons. Sample size was small ( $1 \mathrm{ml}$ wet material), so incomplete ignition is unlikely to have been a problem. Furthermore, the strong stratigraphic correlation between LOI values in Cores I and II also suggests complete ignition was not a problem. Furthermore, measurement errors with the elemental analyzer are highly unlikely. The instrument is routinely tested using carbon-rich materials such as wheat flour, with TOC values $>40 \%$, and should therefore be capable of handling organic-rich lacustrine sediments. In addition, TOC values are not consistently low or high relative to what might be expected from LOI. Instead, there is simply wide scatter.

TOC and LOI values from the Lake Nattmålsvatn cores display corresponding trends over the long time frame (Fig. S1), but the signals diverge in some sections, particularly when $\mathrm{OM}$ exceeds $60 \%$. The 
$\mathrm{TN}$ and $\mathrm{C} / \mathrm{N}$ records enable us to conclude that poor correlation occurs in lake sediments consisting of more nitrogen-rich $\mathrm{OM}$, in the middle and late Holocene.

\section{Calcite dissolution}

Calcite was observed in shallow waters and along the lake shore during fieldwork in July 2002. Greyishwhite coatings on submersed rocks and twigs and marl on the lake bottom confirmed that Nattmålsvatn is a Chara (marl) lake. Langangen (1995) supports this observation, but nonetheless, there is no evidence of carbonate in the core. Several samples were checked for carbonate by XRD analysis and all yielded negative results.

Calcite dissolution in hard-water lakes has been described from other sites, e.g. the Swiss Alps (Ohlendorf and Sturm 2001). Biogenic calcite precipitation in Lake Hagelseewli occurs in late summer as a result of photosynthetic uptake of $\mathrm{CO}_{2}$. The following winter, the precipitated calcite is completely dissolved. The long period of ice cover leads to bottom waters strongly undersaturated with respect to calcite. During ice cover, bottom waters become anoxic and $\mathrm{pH}$ declines.

In the northern part of Norway examined in this study, ice cover on lakes of small to medium size and depth averages 5-7 months (Økland and Økland 1998), but can be longer. Such conditions are similar to those in the Swiss Alps, and winter processes are probably similar in the lakes of both regions. Neither Hagelseewli nor Nattmålsvatn is a "typical" oligotrophic, alkaline water body. For instance, there is considerable decomposition of OM in both lakes. In this study, such decomposition was evident from the strong $\mathrm{H}_{2} \mathrm{~S}$ odor, as well as methanogenesis in the sediments. The organic matter is subject to microbial decomposition, with consequent consumption of $\mathrm{O}_{2}$. Even in an oligotrophic hard-water lake such as Nattmålsvatn, oxygen depletion at the sedimentwater interface may occur, but does not necessarily lead to oxygen depletion of the entire hypolimnion. Similar scenarios are described by Økland and Økland (1998).

In Lake Nattmålsvatn, surface sediments are dominated by particles from high autochthonous organic production during spring and summer, along with precipitated calcite. There are only minor amounts of detrital material. Decomposition of the OM produces slightly acidic conditions at the sediment-water interface with a sufficiently low $\mathrm{pH}$ to dissolve the precipitated calcite. A higher influx of detrital material could possibly 'protect' the calcite from dissolution.

Minerogenic influx and environmental implications

The lowermost part of the core is characterized by greyish silt containing larger clasts, most likely related to the local retreat of the inland ice sheet and/or a local ice cap at Senja (Fig. 1). The sequence reveals high values for ARM, SIRM and $\chi$ bulk that appear to drop relatively rapidly (Fig. 7). Such high values are only surpassed by the brief period centred at 10,250 cal year BP, which might represent the Saksunarvatnet Ash layer (Mangerud et al. 1986, Rasmussen et al. 2007). Although exact dating of the deglaciation may not be possible, its timing can be constrained. The lake was positioned between two ice-sheet margins, the youngest and best defined being the Younger Dryas, referred to locally as the Troms $\varnothing$-Lyngen stage (Andersen 1968). The older one is commonly referred to as the D-event (Vorren and Plassen 2002) (Fig. 1). According to Vorren and Plassen (2002), this event occurred between 13.8 and $13.2{ }^{14} \mathrm{C}$ years BP. Recalibrating the raw ${ }^{14} \mathrm{C}$ dates \pm 150 year with CALIB 5.0.2, the event dates to between $15,890 \pm 270$ and $15,120 \pm 250 \mathrm{cal}$ year BP. Consequently, deglaciation of Lake Nattmålsvatn took place after $15,120 \pm 250$ and before 12,900 cal year BP. Our age-depth model suggests that deglaciation occurred earlier, around 15,400 \pm 250 cal year BP, but this age is tentative. A more likely scenario for deglaciation is the Bølling warming, which started around 14,700 cal year BP, when cirque glaciers in the region started receding (Paasche et al. 2007a).

Holocene minerogenic influx to the lake can be broadly divided into four phases (Fig. 5). The early Holocene transition (P4) included what might be the Saksunarvatnet Ash (10,347 before 2000 AD) (Fig. 7). This interval was followed by a long and stable phase from 9,500 to 4,000 cal year BP, during which there were eight brief ( $<50$ years) episodes with greater minerogenic material. In addition to these short periods, there were two prominent events that lasted 
much longer. The first one spanned the period between 6,850 and 6,500 cal year BP, and the second lasted from about 6,000-5,750 cal year BP (Fig. 5). These episodes of higher minerogenic matter influx probably reflect an increase in runoff from a sustained increase in winter precipitation (Bakke et al. 2010).

At 4,000 cal year BP, a shift occurred in $<100$ years, marking the onset of inferred increased runoff that prevailed for 1,700 years. At 2,300 cal year BP, minerogenic matter increased again and the positive trend continued to the end of the record at $c a$. 1,100 cal year BP. We also interpret these two shifts to indicate wetter winter conditions which might have been related to large-scale atmospheric circulation anomalies. This interpretation is in good accordance with results from northern Fennoscandia (Vorren et al. 2007; Bakke et al. 2005; Paasche et al. 2004, 2007a, b).

Timing of events in the sediment record

In the late glacial period, variations in isotope values $\left(\delta^{13} \mathrm{C}\right.$ and $\left.\delta^{15} \mathrm{~N}\right)$, MS, LOI and $\mathrm{C} / \mathrm{N}$ in the Lake Nattmålsvatn cores occurred synchronously (Figs. 4, $6)$. Vegetation was poorly developed at the time and there was a large influx of detrital particles from the lake catchment. There was a strong correlation between $\delta^{13} \mathrm{C}$ and $\delta^{15} \mathrm{~N}$, and an inverse correlation between the isotope signatures and their respective elemental concentrations (TOC and TN), from the late glacial up to the levels where methane oxidation had a profound influence on the isotope results (Figs. 4, 9). These results are explained by the profound effect of prolonged ice cover on carbon and nitrogen cycling in Lake Nattmålsvatn. The termination of the Younger Dryas and the beginning of the Holocene are not reflected synchronously in variables LOI, TOC and C/N. This is because the relative increase in $\mathrm{OM}$ did not result from increased soil erosion and input of terrestrial plant material, which implies that the gradual depletion of both $\delta^{13} \mathrm{C}$ and $\delta^{15} \mathrm{~N}$ values was not a result of changes in OM source, but rather, changes in DIC and DIN. The decrease in $\chi$ bulk in the early Holocene contrasts with the gradual increase in LOI, indicating less transport of detrital material to the lake (Fig. 6). The increasing LOI values signal a smaller relative amount of detrital material in the sediment. The MS values record a diminishing magnetic signal in sediment that already displayed a weak signal.
In the Holocene, $\mathrm{C} / \mathrm{N}$ ratios were stable. TOC and TN values increased, whereas $\delta^{13} \mathrm{C}$ and $\delta^{15} \mathrm{~N}$ values declined. The $\delta^{13} \mathrm{C}$ reached "steady" values earlier than other variables, indicating that methanogenesis and oxidation of methane began early in the Holocene. Variables other than $\delta^{13} \mathrm{C}$, however, indicate that variations did occur in the Holocene.

The 6,850-6,500 cal year BP event, evident in the isotope and the $\mathrm{LOI}_{550}$ stratigraphies, is the most striking excursion in the Holocene (Fig. 5). The $\mathrm{C} / \mathrm{N}$ signal, however, showed little change. This may indicate sustained lake production in combination with reduced influx of terrestrial OM. Although the event is recorded in both the $\delta^{13} \mathrm{C}$ and $\delta^{15} \mathrm{~N}$ datasets, it is more pronounced in the latter. This probably does not reflect differences in response time between these variables, but may instead indicate that the DIC changed little in the system and that a threshold must be surpassed before a shift in $\delta^{13} \mathrm{C}$ occurs. If winter ice cover helped maintain low $\delta^{15} \mathrm{~N}$ and $\delta^{13} \mathrm{C}$ values, then ice out probably lead to ventilation of depleted DIN and DIC, perhaps changing the $\delta^{13} \mathrm{C}$ values.

In recent years, winters in northern Norway have been mild, and persistent low temperatures have not set in until January and February, resulting in a very short period of ice cover on lakes. Comparable conditions may have existed during the 6,850-6,500 cal year BP event, with mild, wet winters and poorly developed ice cover. Plant growth and algal blooms in summer may have remained unchanged, despite milder winters. Under such a scenario, the composition of OM would not change. For example, the $\mathrm{C} / \mathrm{N}$ ratio would not be affected. Altered winter conditions, however, would change DIN and DIC, and also cause a stronger MS signal, given that greater winter precipitation leads to higher runoff from the catchment, bringing more minerogenic matter into the lake.

From 6,300 to $4,000 \mathrm{cal}$ year BP there was a decline in $\mathrm{C} / \mathrm{N}$ ratio. This decline was probably associated with a relative decrease in the amount of terrestrial OM accumulating in the lake sediments or a gradual increase in aquatic primary production.

Different climate proxies in lake sediments have different thresholds and sensitivities to climate changes that affect a lake and its catchment. Some proxy variables may be highly sensitive, whereas others only respond to major climate and 
environmental changes. Additionally, there may be temporal differences in response among the climate proxies in a paleoclimatic study. The core chronologies and inter-site correlation within a lake may further compromise interpretations. In the Lake Nattmålsvatn records, only the deglaciation events produced synchronous changes among most of the proxies. The deglacial was a period with increased detrital influx and moderate to low amounts of OM in the sediments. Holocene deposits are extremely organic-rich, which seems to have lowered the sensitivity of the climate proxies used in this study, yielding relatively constant values. The exception to this generalization was the $6,850-6,500$ cal year BP event, which is recorded by all proxies except $\mathrm{C} / \mathrm{N}$ ratio. As suggested, most of the proxy variables were probably affected by shifts in winter conditions, whereas the $\mathrm{C} / \mathrm{N}$ ratio stayed rather constant because it reflects organic matter production during summer.

\section{Conclusions}

We presented a high-resolution sediment record from Lake Nattmålsvatn, northern Norway, that spans the last $<15,000 \mathrm{cal}$ year. The Holocene sequence, in particular, is organic-rich, with TOC values up to $45 \%$. Our main conclusions are:

1. Stable isotopes of organic matter $\left(\delta^{13} \mathrm{C}\right.$ and $\left.\delta^{15} \mathrm{~N}\right)$ in sediments do not serve as strong paleoclimate proxies in lakes such as Lake Nattmålsvatn. The large amount of organic matter production and deposition, in combination with methanogenesis and prolonged seasonal ice cover, makes the lake less sensitive to changing environmental conditions. Magnetic variables are better suited to track climate and environmental variations, predominantly fluctuations in winter precipitation that affect catchment runoff.

2. A period of microbially-mediated pyrite formation during the late glacial probably reflects weathering of newly exposed, pyrite-bearing glacial detritus. Once removal of the detrital pyrite was complete, sulphate concentrations in the lake were insufficient to permit formation of early diagenetic pyrite.
3. Isotopic and elemental data suggest that Lake Nattmålsvatn changed from an oligotrophic to a eutrophic waterbody about 8,000 cal year BP.

4. Authigenic feldspar formation during the early Holocene was the result of alkaline conditions in the lake. This was probably due to a warmer and drier climate, which promoted diatom dissolution, thus providing the silica required for feldspar precipitation.

5. Climatic deterioration from 6,850 to $6,500 \mathrm{cal}$ year BP has not been described previously in Scandinavia. This anomaly most likely represents a period of increased winter precipitation and reduced ice cover. A two-step increase in winter precipitation, at 4,000 and 2,300 cal year $\mathrm{BP}$, is indicated by magnetic susceptibility, and corresponds to the 'Holocene Turnover' evident in other paleoclimate studies.

6. Loss-on-ignition (LOI) and elemental analysis revealed a previously undescribed relationship between TOC and $\mathrm{LOI}_{550}$ in organic-rich sediments. At $\mathrm{LOI}_{550}$ values $>60 \%$, there is no longer a linear relationship between $\mathrm{LOI}_{550}$ and TOC. This may reflect variations in the $\mathrm{C} / \mathrm{N}$ ratio of the organic matter. This decoupling of $\mathrm{LOI}_{550}$ and TOC makes it difficult to interpret changes in both proxies or link their variations to to specific climatic conditions. Overall, however, long-term major trends in $\mathrm{LOI}_{550}$ and $\mathrm{TOC}$ were in agreement.

Acknowledgments We thank Jostein Bakke, Bjørn Christian Kvisvik and Asmund Bakke for help with coring of Lake Nattmålsvatn, Nils Erik Janbu for field assistance in 2002, and Karl Fredrik Alnes for proofreading. We also extend our thanks to Prof. Reidar Løvlie and Prof. Ann Hirt for use of the Paleomagnetic Laboratory in Bergen (UIB) and the Laboratory for Natural Magnetism in Zürich (ETH), respectively. The Norwegian Geological Survey (NGU) performed the LECO and XRD analyses. This work was financed by a Norwegian Research Council grant through NORPEC, a Strategic University Program (SUP) at the University of Bergen, led by Prof. H.J.B. Birks. Finally, we offer our sincere thanks to two anonymous reviewers and especially Editor-in-Chief Mark Brenner for valuable feedback. This is publication nr. A321 from the Bjerknes Centre of Climate Research.

Open Access This article is distributed under the terms of the Creative Commons Attribution Noncommercial License which permits any noncommercial use, distribution, and reproduction in any medium, provided the original author(s) and source are credited. 


\section{References}

Andersen BG (1968) Glacial geology of Western Troms, North Norway. Norwegian Geological Survey 256:160

Bade DL, Carpenter SR, Cole JJ, Hanson PC, Hesslein RH (2004) Controls of $\delta^{13} \mathrm{C}$-DIC in lakes: Geochemistry, lake metabolism, and morphometry. Limnol Oceanogr 49:1160-1172

Bakke J, Dahl SO, Paasche $\varnothing$, Løvlie R, Nesje A (2005) Glacier fluctuations, equilibrium line altitudes and palaeoclimate in Lyngen, northern Norway, during the Lateglacial and the Holocene. The Holocene 15:518-540

Bakke J, Dahl SO, Paasche $\varnothing$, Simonsen JR, Kvisvik BC, Bakke K, Nesje A (2010) A complete record of Holocene glacier variability at Austre Okstindbreen, northern Norway: an integrated approach. Quat Sci Rev 29:1246-1262

Billaud VA (1968) Nitrogen fixation and utilization of other nitrogen sources in a subarctic lake. J Fish Res Bd Can 25:263-269

Birks HH, Klitgaard-Kristensen D, Dokken TM, Andersson C (2005) Explanatory comparisons of quantitative temperature estimates over the last deglaciation in Norway and the Norwegian Sea. In: Drange H, Dokken TM, Furevik T, Gerdes R, Berger W (eds) The Nordic Seas; An integrated perspective; oceanography, climatology, biogeochemistry, and modeling, geophysical monograph, vol 158. AGU, Washington, pp 341-355

Bjune AE, Bakke J, Nesje A, Birks HJB (2005) Holocene mean July temperature and winter precipitation in western Norway inferred from palynological and glaciological lake-sediment proxies. The Holocene 15:177-189

Boström B, Pettersson K (1977) The spring development of phytoplankton in Lake Erken. Freshw Biol 7:327-335

Bradbury JP, Dean WE (1993) Elk Lake-Minnesota: evidence for rapid climate change in the north-central United States. Geological Society of America Special Paper No. 276, Boulder

Bradley RS (1999) Paleoclimatology, Geophysics Series, vol 64, 2nd edn. Academic Press Int., Burlington

Coplen TB (1982) New guidelines for reporting stable hydrogen, carbon and oxygen isotope-ratio data. Geochim Cosmochim Ac 60:3359-3360

Dean WE (1974) Determination of carbonate and organic matter in calcareous sediments and sedimentary rocks by loss on ignition: comparison with other methods. J Sediment Petrol 44:242-248

Degens ET, Guillard RRL, Sackett WM, Hellebust JA (1968) Metabolic fractionation of carbon isotopes in marine plankton, I, Temperature and respiration experiments. Deep Sea Res 15:1-9

Diefendorf AF, Patterson WP, Holmden C, Mullins HT (2008) Carbon isotopes of marl and lake sediment organic matter reflect terrestrial landscape change during the late Glacial and early Holocene $(16,800$ to 5, 540 cal year B.P.): a multiproxy study of lacustrine sediments at Lough Inchiquin, western Ireland. J Paleolimnol 39:101-115

Evans ME, Heller F (2003) Environmental Magnetism-Principles and Applications of Environmagnetics, 293 pp. Academic Press, Amsterdam
Filippi ML, Talbot MR (2004) The palaeolimnology of northern Lake Malawi over the last $25 \mathrm{ka}$ based upon the elemental and stable isotopic composition of sedimentary organic matter. Quat Sci Rev 24:1303-1328

Hammarlund D, Björck S, Buchardt B, Israelson C, Thomsen C (2003) Rapid hydrological changes during the Holocene revealed by stable isotope records of lacustrine carbonates from Lake Igelsjön, southern Sweden. Quat Sci Rev 22:353-370

Hollander DJ, McKenzie JA (1991) $\mathrm{CO}_{2}$ control on carbon isotope fractionation during aqueous photosynthesis: a paleo-pCO $\mathrm{pO}_{2}$ barometer. Geology 19:929-932

Huttunen JT, Alm J, Liikanen A, Juutinen S, Larmola T, Hammar T, Silvola J, Martikainen PJ (2003a) Fluxes of methane, carbon dioxide and nitrous oxide in boreal lakes and potential anthropogenic effects on the aquatic greenhouse gas emissions. Chemosphere 52:609-621

Huttunen JT, Alm J, Saarijrvi E, Lappalainen KM, Silvola J, Martikainen PJ (2003b) Contribution of winter to the annual $\mathrm{CH}_{4}$ emission from a eutrophied boreal lake. Chemosphere 50:247-250

Kelts K, Hsü K (1978) Freshwater carbonate sedimentation. In: Lerman A (ed) Lakes-chemistry, geology, physics. Springer, New York, pp 295-323

Klimaavdelingen DNMI 1993. Temperaturnormaler 1961-1990

Klimaavdelingen DNMI 1993. Nedbørsnormaler 1961-1990

Kortelainen P, Huttunen JT, Vaisanen T, Mattsson T, Karjalainen P, Martikainen PJ (2000) $\mathrm{CH}_{4}, \mathrm{CO}_{2}$ and $\mathrm{N}^{2} \mathrm{O}$ supersaturation in 12 Finnish lakes before and after icemelt. Verh int Ver Limnol 27:1410-1414

Langangen A (1995) Kalksjøer i Troms. Polarflokken 19:111-118

Langangen A (2004) Kalksjøer med kransalgevegetasjon i Norge III. Beskrivelser av sjøer i Nordland, Troms og Finnmark. Blyttia 62:198-211

Leng MJ, Marshall JD (2004) Palaeoclimate interpretation of stable isotope data from lake sediment archives. Quat Sci Rev 23:811-831

Mangerud J, Furnes HJ, Johanssen J (1986) A 9000-year old ash bed on the Faroe Islands. Quat Res 26:262-265

Meyers PA, Lallier-Vergés E (1999) Lacustrine sedimentary organic matter records of Late Quaternary paleoclimates. J Paleolimnol 21:345-372

Meyers PA, Teranes JL (2001) Sediment organic matter. In: Last WM, Smol JP (eds) Tracking environmental change using lake sediments: physical and geochemical methods. Springer, Berlin, pp 239-269

Nesje A (1992) A piston corer for lacustrine and marine sediments. Arct Antarct Alp Res 24:257-259

Noe-Nygaard N (1995) Ecological, sedimentary, and geochemical evolution of the late-glacial to postglacial mose lacustrine basin, Denmark. Fossil Strat 37:1-436

Ohlendorf C, Sturm M (2001) Precipitation and Dissolution of Calcite in a Swiss High Alpine Lake. Arct Antarct Alp Res 33:410-417

Økland J and Økland KA (1998) Vann og vassdrag 3. Kjemi, fysikk og miljø. Vett og Viten as. $200 \mathrm{pp}$

Paasche Ø, Løvlie R, Dahl SO, Bakke J, Nesje A (2004) Bacterial magnetite in lake sediments: late glacial to Holocene climate and sedimentary changes in northern Norway. Earth Planet Sci Lett 223:319-333 
Paasche O, Dahl SO, Bakke J, Løvlie R, Nesje A (2007a) Cirque glacier activity in arctic Norway during the last deglaciation. Quat Res 68:387-399

Paasche O, Dahl SO, Løvlie R, Bakke J, Nesje A (2007b) Rockglacier activity during the Last Glacial_Interglacial transition and Holocene spring snowmelting. Quat Sci Rev 26:793-807

Rasmussen SO, Vinther BM, Clausen HB, Andersen KK (2007) Early Holocene climate oscillations recorded in three Greenland ice cores. Quat Sci Rev 26:1907-1914

Rau G (1978) Carbon-13 Depletion in a Subalpine Lake. Carbon Flow Implications. Science 201:901-902

Stober JC, Thompson R (1979) Magnetic remanence acquisition in Finnish lake sediments. Geophys J Roy Astron Soc 57:727-739

Striegl RG, Kortelainen P, Chanton JP, Wickland KP, Bugna GC, Rantakari M (2001) Carbon dioxide partial pressure and $13 \mathrm{C}$ content of north temperate and boreal lakes at spring ice melt. Limnol Oceanogr 46:941-945

Stuiver M, Reimer PJ, Reimer RW (2005) CALIB 5.0. [http://radiocarbon.pa.qub.ac.uk/calib/]

Talbot MR (2001) Nitrogen isotopes in lacustrine Paleolimnology. In: Last WM, Smol JP (eds) Tracking environmental change using lake sediments: physical and chemical techniques, developments in palaeoenvironmental research, vol 2. Kluwer Academinc Publishers, Berlin, pp 401-439

Talbot MR, Johannessen T (1992) A high resolution palaeoclimatic record for the last 27, 500 years in tropical West
Africa from the carbon and nitrogen isotopic composition of lacustrine organic matter. Earth Planet Sci Lett 110: 23-37

Teranes JL, McKenzie JA, Lotter AF, Sturm M (1999) Stable isotope response to lake eutrophication: Calibration of a high-resolution lacustrine sequence from Baldeggersee, Switzerland. Limnol Oceanogr 44:320-333

Thompson R, Oldfield F (1986) Environmental magnetism. Allenand Unwin, Concord, Mass

Vorren TO, Plassen L (2002) Deglaciation and palaeoclimate of the Andfjord-Vågsfjord area, North Norway. Boreas 31:97-125

Vorren TO, Vorren KD, Alm T, Gulliksen S, Løvlie R (1988) The last deglaciation (20, 000-11, 000 BP) on Andøya, northern Norway. Boreas 17:41-77

Vorren KD, Blaauw M, Wastegård S, van der Plicht J, Jensen C (2007) High-resolution stratigraphy of the northernmost concentric raised bog in Europe: Sellevoldmyra, Andøya, northern Norway. Boreas 36:253-277

Wetzel RG (2001) Limnology: Lake and River Systems. San Diego, Academic Press, p 1006

Whiticar MJ, Faber E (1986) Methane oxidation in sediment and water column environments - isotope evidence. Org Geochem 10:759-768

Wolfe BB, Edwards TWD, Aravena R (1999) Changes in carbon and nitrogen cycling during tree-line retreat recorded in the isotopic content of lacustrine organic matter, western Taimyr Peninsula, Russia. The Holocene 9:215-222 